UNIVERSIDADE DE SÃO PAULO

ESCOLA DE EDUCAÇÃO FÍSICA E ESPORTE

\title{
EFEITO DO EXERCícIO FÍSICO AERÓBICO NO RELAXAMENTO AÓRTICO DE RATOS E NO CONTROLE DA BIODISPONIBILIDADE DO ÓXIDO NÍTRICO
}

Leonardo Yuji Tanaka

SÃO PAULO

2008 